\title{
Androgens, diabetes and prostate cancer
}

\author{
Mathis Grossmann and Gary Wittert ${ }^{1}$
}

Department of Medicine Austin Health, University of Melbourne, Studley Road, Heidelberg, Victoria 3084, Australia ${ }^{1}$ Discipline of Medicine, Royal Adelaide Hospital, University of Adelaide, Level 6, Eleanor Harrald Building, Adelaide, South Australia 5000, Australia

(Correspondence should be addressed to G Wittert; Email: gary.wittert@adelaide.edu.au)

\begin{abstract}
Metabolic disorders such as diabetes, obesity and the metabolic syndrome have been shown to modulate prostate cancer ( $\mathrm{PCa}$ ) risk and aggressiveness in population-based and experimental studies. While associations between these conditions are modest and complex, two consistent findings have emerged. First, there is observational evidence that obesity and associated insulin excess are linked to increased PCa aggressiveness and worse outcomes. Secondly and somewhat paradoxically, long-standing diabetes may be protective against PCa development. This apparent paradox may be due to the fact that long-standing diabetes is associated with insulin depletion and decreased IGF1 signalling. Men with obesity or diabetes have moderate reductions in their androgen levels. The interconnectedness of metabolic and androgen status complicates the dissection of the individual roles of these factors in PCa development and progression. Metabolic factors and androgens may promote prostate carcinogenesis via multiple mechanisms including inflammation, adipokine action, fatty acid metabolism and IGF signalling. Moreover, androgen deprivation, given to men with $\mathrm{PCa}$, has adverse metabolic consequences that need to be taken into account when estimating the risk benefit ratio of this therapy. In this review, we will discuss the current epidemiological and mechanistic evidence regarding the interactions between metabolic conditions, sex steroids and PCa risk and management.
\end{abstract}

Endocrine-Related Cancer (2012) 19 F47-F62

\section{Introduction}

Diabetes and prostate cancer $(\mathrm{PCa})$ are two major, growing health problems that affect millions of men worldwide. $\mathrm{PCa}$ is the most common solid organ cancer in men in the USA, Canada and Australia, and the second most common cancer in men globally. US men have a current estimated lifetime risk of one in six (Siegel et al. 2011) and PCa represents, after lung cancer, the second leading cause of cancer-related mortality (Jemal et al. 2010). Established risk factors of PCa are older age, African American Ethnicity and a history of the disease in a first-degree relative. PCa has one of the strongest relationships between age for any human cancer, and genetic factors are estimated to account for $42 \%$ of the risk (Lichtenstein et al. 2000). Genome-wide association studies (GWAS) in mostly Caucasian populations have, to date, found more than 30 single nucleotide polymorphisms (SNPs) that are consistently associated with PCa (Kim et al. 2010). However, the magnitude of risk elevation attributable to individual SNPs is low (odds ratio $(\mathrm{OR})<1.30$ ), and these SNPs in aggregate are estimated to account for only one-quarter of the total genetic variance of $\mathrm{PCa}$ risk (Kote-Jarai et al. 2011). Recently, there has been an increasing interest in the role of metabolic factors, such as disordered glucose metabolism, in the aetiology and pathogenesis of PCa. This is important not only because life expectancy is increasing globally, but also because of the global increase in the prevalence of diabetes, predicted to increase by $69 \%$ in developing countries and by $20 \%$ in developed countries over the next 20 years (Shaw et al. 2010).

While it has long been known that established PCa is an androgen-dependent malignancy (Huggins \& Hodges 1941), the roles of androgens in initiation of prostate carcinogenesis are less well understood. This in part because there is a complex relationship between metabolic disorders and circulating androgens in men (Atlantis et al. 2009, Mah \& Wittert 2010, Araujo \& Wittert 2011, Grossmann 2011), both of which may affect prostate biology in different ways. Moreover, the role of androgen deprivation therapy (ADT) for $\mathrm{PCa}$ 
continues to evolve, with both efficacy and side effects of this treatment coming into sharper focus. ADT has been associated with an increased risk of diabetes in observational and experimental studies (Grossmann \& Zajac 2011b). This is concerning given the overall good prognosis for most men with $\mathrm{PCa}$, with a contemporary 5-year relative survival rate for all stages of PCa combined of $98.8 \%$. Indeed, more than $30 \%$ of men with PCa die of cardiovascular disease, which constitutes one of the most common causes of death (Satariano et al. 1998) in this patient population.

In this review, we examine the observational evidence and the proposed mechanisms linking diabetes and androgens to $\mathrm{PCa}$ epidemiology and biology. We also discuss the effect of ADT on PCa, and provide recommendations for future research.

\section{Evidence acquisition}

The clinical and experimental studies discussed in this review were retrieved from the peer-reviewed journals indexed on the PubMed database from 1970 to February 2012. Multiple searches were performed, using the search terms PCa, testosterone, androgen, diabetes, insulin resistance, metabolic syndrome (MetS) and males. In addition, references listed in published meta-analyses were reviewed.

\section{Metabolic risk factors for PCa: evidence from population-based studies}

\section{Obesity}

Substantial geographic variations in $\mathrm{PCa}$ prevalence, not fully accounted for by ascertainment bias (e.g. volume of prostate specific antigen (PSA) testing), suggest that environmental and lifestyle factors may contribute to $\mathrm{PCa}$ aetiology and pathogenesis. For example, migrant studies have shown that Asian men living in the USA have much higher PCa rates than their counterparts living in native lands, and the incidence of $\mathrm{PCa}$ in previously low-risk Asian countries has increased in parallel to affluence. This suggested that westernization may represent an important risk factor for $\mathrm{PCa}$ (Hsing et al. 2007). However, multiple observational studies have given conflicting evidence regarding the relationship of obesity and PCa (Table 1). A meta-analysis of observational studies including more than 68000 men with $\mathrm{PCa}$ found that increasing body mass index (BMI) was weakly associated with an increased risk of $\mathrm{PCa}$, with an overall relative risk (RR) of 1.05 per $5 \mathrm{~kg} / \mathrm{m}^{2}$ increment (95\% confidence interval (CI), 1.01-1.08) (MacInnis \& English 2006). This risk increase was significant only for advanced disease (RR, 1.12 per $5 \mathrm{~kg} / \mathrm{m}^{2}$ increment; 95\% CI, 1.01-1.23) but not for localised disease (RR, 0.96 per $5 \mathrm{~kg} / \mathrm{m}^{2}$ increment; 95\% CI, 0.89-1.03) (MacInnis \& English 2006).

Table 1 PCa and obesity: population-based studies

\begin{tabular}{|c|c|c|c|}
\hline Author & Study design & Study population & Main study findings \\
\hline $\begin{array}{l}\text { Maclnnis \& } \\
\text { English } \\
(2006)\end{array}$ & $\begin{array}{l}\text { Meta-analysis of } \\
\text { observational } \\
\text { studies }\end{array}$ & $\begin{array}{l}55521 \text { cases identified } \\
\text { among } 2818767 \text { men from } \\
31 \text { cohort studies and } \\
13232 \text { cases and } 16317 \\
\text { controls from } \\
25 \text { case-control studies }\end{array}$ & $\begin{array}{l}\text { Overall RR for BMI: } 1.05 \text { per } 5 \mathrm{~kg} / \mathrm{m}^{2} \text { increment, }(95 \% \mathrm{Cl} \text {, } \\
1.01-1.08) \text {. RR stronger for advanced disease (RR } 1.12 \text { per } \\
\left.5 \mathrm{~kg} / \mathrm{m}^{2} \text { increment; } 95 \% \mathrm{Cl}, 1.01-1.23\right) \text { compared with } \\
\text { localised disease (RR } 0.96 \text { per } 5 \mathrm{~kg} / \mathrm{m}^{2} \text { increment; } 95 \% \mathrm{Cl} \text {, } \\
0.89-1.03), P=0.02 \text {. Stronger associations were observed } \\
\text { among cohort studies compared with case-control studies } \\
\text { for BMI }(P=0.006) \text { and weight }(P=0.02)\end{array}$ \\
\hline $\begin{array}{l}\text { Rodriguez } \\
\text { et al. (2007) }\end{array}$ & $\begin{array}{l}\text { Prospective cohort } \\
\text { study with } \\
\text { 11-year } \\
\text { follow-up }\end{array}$ & $\begin{array}{c}69991 \text { men with } 5252 \\
\text { incident PCa cases }\end{array}$ & $\begin{array}{l}\text { Inverse association of } \mathrm{BMI} \text { with low-grade } \mathrm{PCa}(\mathrm{RR}, 0.84 ; 95 \% \\
\mathrm{Cl}, 0.66-1.06) \text {. Positive association of } \mathrm{BMI} \text { with high-grade } \\
\mathrm{PCa}(\mathrm{RR}, 1.22 ; 95 \% \mathrm{Cl}, 0.96-1.55) \text { and risk of metastatic or } \\
\text { fatal } \mathrm{PCa}(\mathrm{RR}, 1.54 ; 95 \% \mathrm{Cl}, 1.06-2.23) \text {. Compared with } \\
\text { weight maintenance, men who lost }>11 \text { pounds during } \\
\text { follow-up were at a decreased risk of high-grade } \mathrm{PCa} \\
(\mathrm{RR}, 0.58 ; 95 \% \mathrm{Cl}, 0.42-0.79)\end{array}$ \\
\hline $\begin{array}{l}\text { Su et al. } \\
\text { (2011) }\end{array}$ & $\begin{array}{l}\text { Population-based } \\
\text { incident PCa } \\
\text { study }\end{array}$ & $\begin{array}{l}1049 \text { African American and } \\
1083 \text { Caucasian American } \\
\text { men with newly diagnosed } \\
\text { PCa }\end{array}$ & $\begin{array}{l}\text { ORs for aggressive PCa among pre-diagnosis obese and } \\
\text { severely obese were } 1.48(95 \% \mathrm{Cl}, 1.02-2.16) \text { and } 1.98 \\
(95 \% \mathrm{Cl}, 1.31-2.97) \text { respectively compared with normal } \\
\text { weight subjects. Race-stratified results suggested the } \\
\text { association was stronger among Caucasian American men. } \\
\text { WHR }>0.98 \text { among all research subjects adjusted for race } \\
\text { was significantly associated with aggressive } \mathrm{PCa}(\mathrm{OR}=1.42 \text {; } \\
95 \% \mathrm{Cl}, 1.00-2.00) \text { when compared with WHR }<0.90\end{array}$ \\
\hline
\end{tabular}

$\mathrm{RR}$, relative risk; $\mathrm{Cl}$, confidence interval; BMI, body mass index; OR, odds ratio; WHR, waist hip ratio. 
The positive association of obesity with increased $\mathrm{PCa}$ aggressiveness has since been confirmed in more recent observational studies (Rodriguez et al. 2007, Su et al. 2011). Thus, obesity may reduce the risk of non-aggressive $\mathrm{PCa}$, while at the same time promote the risk of aggressive $\mathrm{PCa}$. Part of this relationship may be explained by detection bias. Given that adiposity is associated with decreased PSA values, larger prostate gland size and more difficult digital rectal examination (Stewart \& Freedland 2011), PCa may be underdiagnosed in obese men. In addition, obese men receiving treatment for $\mathrm{PCa}$ have worse surgical and radiation treatment outcomes that are related not only to technical challenges, but may also reflect inherent differences in tumour biology (Ma et al. 2008, Smith et al. 2008).

\section{The MetS}

The association of the MetS with $\mathrm{PCa}$ has been assessed in multiple observational studies, which have yielded conflicting results (Table 2). There have been three larger prospective cohort studies in the USA (Tande et al. 2006) and Norway (Lund Haheim et al. 2006, Martin et al. 2009) comprising 6500 (Tande et al. 2006), 16000 (Lund Haheim et al. 2006) and 29000 (Martin et al. 2009) men initially free of PCa who were followed up between 9 and 27 years. Incident PCa was diagnosed in 385 (Tande et al. 2006), 507 (Lund Haheim et al. 2006) and 687 (Martin et al. 2009) men respectively. After exclusion of men with diabetes, baseline presence of the MetS, assessed by NCEP-ATP-III criteria, was associated either with a reduced risk of $\mathrm{PCa}(\mathrm{RR}, 0.77$; 95\% CI, 0.60-0.98) (Tande et al. 2006), an increased risk of PCa (RR for three MetS components $1.56 P<0.01$; Lund Haheim et al. 2006), or no significant risk of PCa (Martin et al. 2009). These divergent results are in part explained by differences in study populations, analytical methods, definitions used to define the MetS and length of follow-up. Conflicting results may also relate to differential or even opposing effects of individual components of the MetS on prostate carcinogenesis. For example, the dynamic association of insulin action with $\mathrm{PCa}$, discussed further below, may confound the relationship of the MetS with PCa. In addition, noncancer-related mortality may influence the observed associations of a given variable with cancer incidence. Men who die of other causes are no longer at risk for cancer, a concept that is known as competing risk. This concept is particularly relevant for cancers with a long natural history and strong age-dependence such as PCa. Conceivably, men with adverse metabolic risk factors may not live to an age where PCa is the highest, leading to an under-estimation of the association of the MetS with PCa. Indeed, in a prospective study of 2322 Swedish men followed up for 34 years, the increased risk of MetS for PCa became significant only after death from other causes was taken into account

Table 2 PCa and the MetS: population-based studies

\begin{tabular}{|c|c|c|c|}
\hline Author & Study design & Study population & Main study findings \\
\hline $\begin{array}{c}\text { Tande et al. } \\
\text { (2006) }\end{array}$ & $\begin{array}{l}\text { Prospective cohort } \\
\text { study with } \\
\text { 13-year } \\
\text { follow-up }\end{array}$ & $\begin{array}{l}6429 \text { US American men } \\
\text { (aged } 45-64 \text { at baseline) } \\
\text { with } 385 \text { incident PCa cases }\end{array}$ & $\begin{array}{l}\text { Men with the MetS ( } \geq 3 \text { components according to the ATP III } \\
\text { definition) were significantly less likely to develop } \mathrm{PCa} \\
(\mathrm{RR}=0.77 ; 95 \% \mathrm{Cl}, 0.60-0.98) \text { than men without the MetS }\end{array}$ \\
\hline $\begin{array}{l}\text { Lund Haheim } \\
\text { et al. (2006) }\end{array}$ & $\begin{array}{l}\text { Prospective cohort } \\
\text { study with } 27 \\
\text { year follow-up }\end{array}$ & $\begin{array}{l}15933 \text { Norwegian men } \\
\text { (aged } 40-49 \text { at baseline) } \\
\text { with } 507 \text { incident PCa cases }\end{array}$ & $\begin{array}{l}\text { Combinations of any two }(\mathrm{RR}=1.23 ; P=0.04) \text { or any three } \\
(\mathrm{RR}=1.56 ; P=0.00) \text { components of the MetS (according } \\
\text { to the NCEP definition) using quartile values of risk factors } \\
\text { were predictive of } \mathrm{PCa}\end{array}$ \\
\hline $\begin{array}{l}\text { Martin et al. } \\
\text { (2009) }\end{array}$ & $\begin{array}{l}\text { Prospective cohort } \\
\text { study with } \\
\text { 9.3-year } \\
\text { follow-up }\end{array}$ & $\begin{array}{l}29364 \text { Norwegian men (aged } \\
44-62 \text { at baseline) with } \\
687 \text { incident PCa cases, } \\
\text { and } 110 \text { PCa deaths }\end{array}$ & $\begin{array}{l}\text { No association of baseline BMI, WC, WHR, total or HDL- } \\
\text { cholesterol, triglycerides, presence of the MetS, diabetes, } \\
\text { anti-hypertensive use, or cardiovascular disease with } \\
\text { incident or fatal PCa. Raised blood pressure was weakly } \\
\text { associated with an increased risk: for each s.D. ( } 12 \mathrm{~mm}) \\
\text { increase in diastolic blood pressure, there was an } 8 \% \\
(95 \% \mathrm{Cl}, 1-17 \% ; P=0.04) \text { increased risk of incident } \mathrm{PCa}\end{array}$ \\
\hline $\begin{array}{l}\text { Grundmark } \\
\quad \text { et al. (2010) }\end{array}$ & $\begin{array}{l}\text { Prospective cohort } \\
\text { study with } \\
\text { 32-year } \\
\text { follow-up }\end{array}$ & $\begin{array}{l}2322 \text { Swedish men (aged } \\
46-54 \text { at baseline) with } \\
237 \text { incident PCa cases }\end{array}$ & $\begin{array}{l}\text { Conditional probability of PCa considering death from other } \\
\text { causes was significantly higher }(7.3 \text { percent-units }(95 \% \mathrm{Cl} \text {, } \\
0.2-14.5 \%) \text {; OR of } 1.64(95 \% \mathrm{Cl}, 1.03-2.23 ; \mathrm{NCEP})) \text { and } \\
\text { non-significantly higher (5.0 percent-units (Cl, }-1.6 \% \text { to } \\
11.6 \%) \text {; OR of } 1.43(95 \% \mathrm{Cl}, 0.89-1.90 ; \text { IDF) }\end{array}$ \\
\hline
\end{tabular}

ATP III, Adult Treatment Panel III; NCEP, National Cholesterol Education Program, IDF, International Diabetes Foundation; RR, relative risk; $\mathrm{Cl}$, confidence interval; $\mathrm{BMI}$, body mass index; OR, odds ratio; WC, waist circumference; and WHR, waist hip ratio. 
(Grundmark et al. 2010). In this study, the predominant components responsible for the increased $\mathrm{PCa}$ risk were abdominal obesity and a high serum triglyceride level (Grundmark et al. 2010). In contrast, in the HUNT 2 cohort, among individual components of the MetS, only hypertension was associated with increased PCa risk (Martin et al. 2009).

\section{Diabetes}

A meta-analysis of 19 population-based studies published between 1971 and 2005 showed that men with diabetes had a $16 \%$ reduction in their risk of PCa (Kasper \& Giovannucci 2006) (Table 3). An early analysis from the Health Professionals Follow-Up study from 1986 to 1994 showed that this reduced risk only occurred from at least 5 years after the diagnosis of diabetes (Giovannucci et al. 1998). A subsequent report from the same cohort extending the follow-up to 2004 including a total of 4511 new PCa cases confirmed that PCa risk was not reduced in the first year after diabetes diagnosis (hazard ratio (HR): 1.30, CI: $0.97,1.72)$, but was lower for men diagnosed for 1-6 years (HR: 0.82, CI: 0.66, 1.02), and even lower for men who had been diagnosed for $6-15$ years (HR: 0.75 , CI: $0.61,0.93$ ) or $>15$ years (HR: 0.78 , CI: 0.63 , 0.96). This decreased risk of $\mathrm{PCa}$ in men with diabetes was irrespective of current or previous BMI, and interestingly, reduced $\mathrm{PCa}$ risk was stronger in men diagnosed before 1994 (pre-PSA era) vs after 1994 (Kasper et al. 2009). Similarly, an observational study of the prospective Cancer Prevention Study II Nutrition cohort confirmed that diabetes was associated with a reduced risk of $\mathrm{PCa}$, but only 4 years after the diagnosis of diabetes (Rodriguez et al. 2005). A large populationbased prospective multi-ethnic study among 86303 men including $5941 \mathrm{PCa}$ cases found that diabetes reduced the risk of $\mathrm{PCa}$ consistently among ethnic groups, with RRs ranging from 0.65 (95\% CI, 0.50-0.84) among European Americans to 0.89 (95\% CI, 0.77-1.03) among African Americans (Waters et al. 2009). Although both PSA levels and PSA testing frequencies were significantly lower in men with diabetes when compared with men without diabetes, the authors estimated that this explained only $20 \%$ of the inverse association of diabetes with PCa (Waters et al. 2009). The fact that this protective effect of diabetes on PCa is not simply a consequence of detection bias is supported by findings from a cohort of men from the Prostate Cancer Prevention Trial, who had prostate biopsies regardless of PSA (Gong et al. 2006). In this cohort, diabetes was not only associated with an overall decreased risk of PCa but also associated with $28 \%$
(OR, 0.72; 95\% CI, 0.55-0.94) reduced risk of high-grade $\mathrm{PCa}$, which argues against detection bias from delayed diagnosis. Explanations proposed for the protective effect of diabetes have included the progressive development of $\beta$-cell exhaustion with insulin depletion, the association of diabetes with lower testosterone and lower insulin-like growth factor 1 (IGF1) levels or genetic effects operating in different directions (Elliott et al. 2010, Meyer et al. 2010, Stevens et al. 2010), the evidence for which we will discuss in subsequent sections. A recent analysis of the Swedish Apolipoprotein Mortality database including 200660 men, 5112 of whom developed PCa, used competing risk analysis to show that conventional Cox proportional hazard models, employed in previous studies, may over-estimate the prospective effects of increased glucose levels on PCa risk (Van Hemelrijck et al. 2011). This over-estimation of risk occurred because high glucose levels increased the probability of early death, thus masking PCa risk (Van Hemelrijck et al. 2011).

Although long-standing diabetes may protect against $\mathrm{PCa}$ development, there is evidence that diabetic men with PCa may have a worse outcome. In a prospective study, among men who developed PCa, diabetes was associated with a higher risk of cancer case fatality and all-cause mortality (Yeh et al. 2012). However, an analysis of the RTOG 92-02 randomised controlled trial (RCT) comparing short-term vs long-term adjuvant goserelin for men with locally advanced PCa receiving radiation therapy concluded that while diabetes was associated with increased all-cause and non-PCa-related mortality, the association of diabetes with increased PCa mortality was driven by obesity (Smith et al. 2008).

\section{Metabolic risk factors for PCa: possible mechanisms}

The possible mechanisms mediating the effects of metabolic risk factors on prostate carcinogenesis are summarised in Fig. 1.

\section{Genetics}

Among the risk SNPs identified in GWAS of PCa, several PCa susceptibility loci such as $H N F 1 \beta$ (TFC2), $J A Z F 1$ and THADA have also been shown to be associated with diabetes risk (Gudmundsson et al. 2007, Zeggini et al. 2008). Interestingly, HNF1 $\beta$ mutations have been associated with maturity-onset diabetes of the young type 5 (MODY5), which presents with pancreatic atrophy and early insulin requirement. 


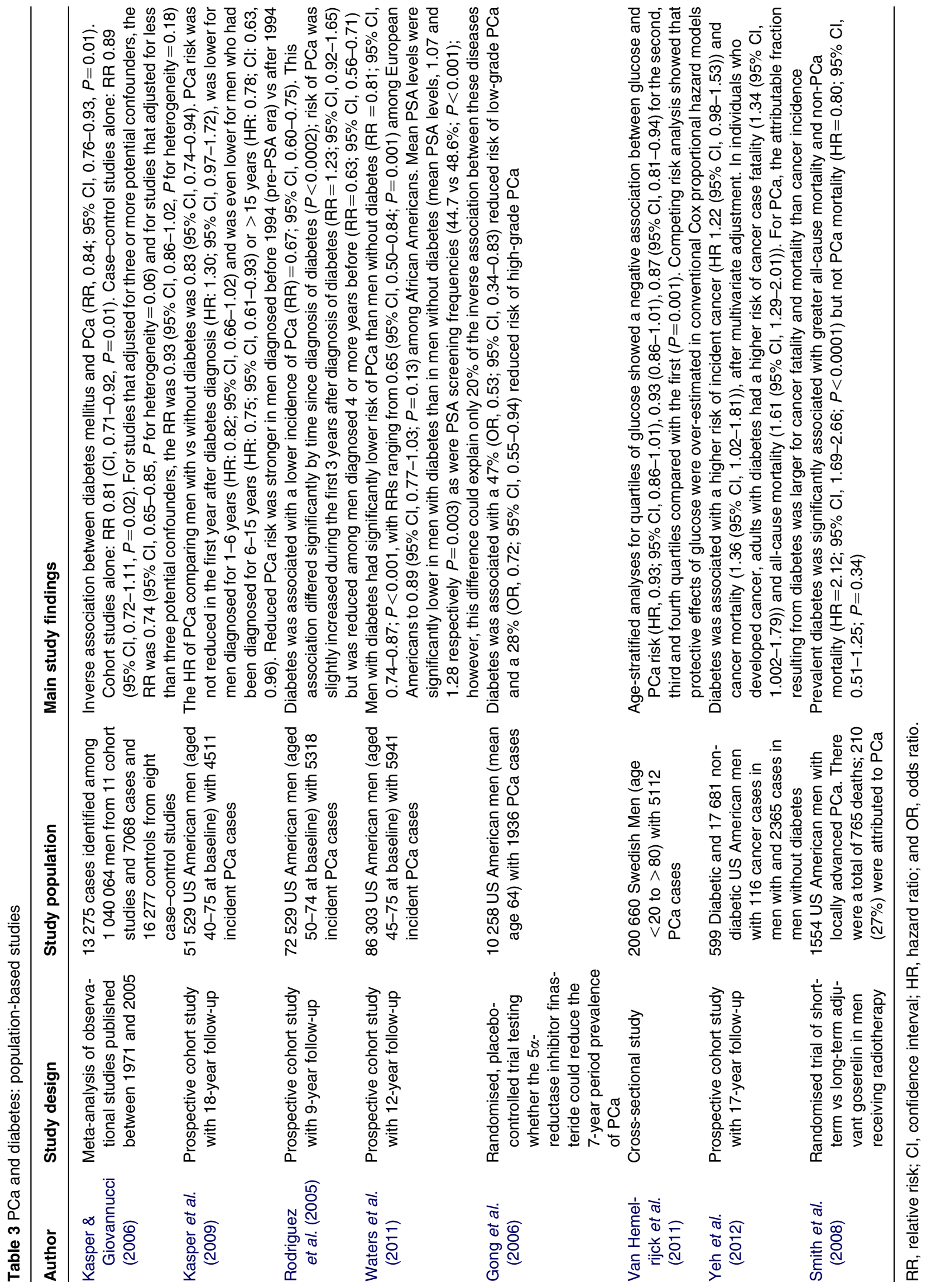




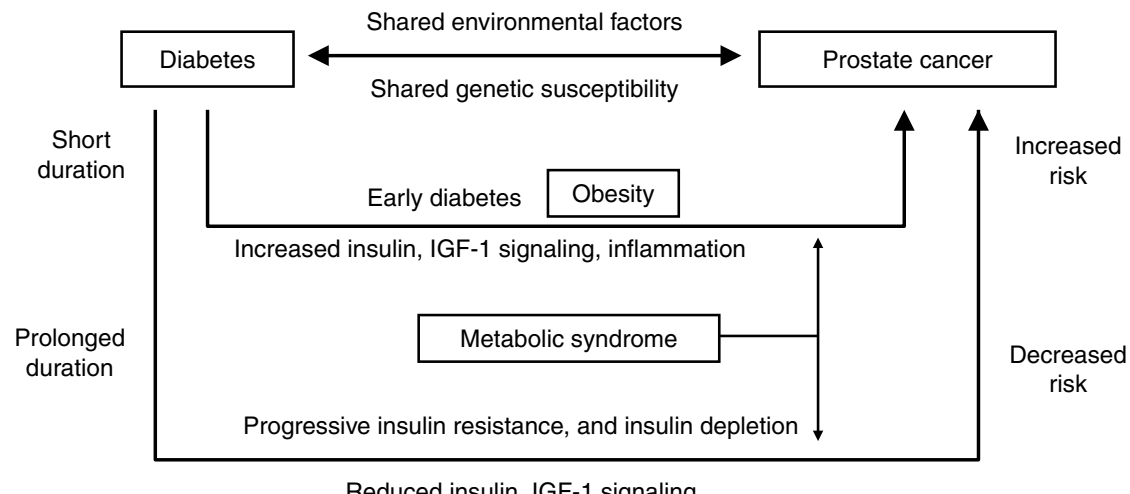

Reduced insulin, IGF-1 signaling

Figure 1 Metabolic risk factors for prostate cancer: possible mechanisms.

While the MODY5 phenotype is consistent with the observational studies suggesting a protective effect of insulin depletion, a recent study concluded that the relationship between $H N F 1 \beta$ and JAZF1 variants with decreased PCa was not mediated by diabetic status (Stevens et al. 2010). A further study testing 17 diabetes risk variants in a PCa case-control study of 2746 cases and 3317 controls from five racial/ethnic groups in the Multiethnic Cohort (MEC) study did not find any association of any of the diabetes loci with $\mathrm{PCa}$ risk (Waters et al. 2011). Given that the relationship of diabetes with PCa is likely a complex interplay between environmental factors and pleiotropic genetic effects that may vary in a diabetes- and PCa stage-dependent fashion, further study is required to evaluate the shared genetic components of diabetes and PCa.

\section{Insulin and IGF1}

Although the results from population-based studies discussed above are somewhat complex and the overall strengths of the associations are modest, two consistent findings have emerged. First, obesity appears to be associated with increased risk of high-grade PCa and with increased PCa mortality, and possibly, with reduced low-risk PCa. Secondly and somewhat paradoxically given its strong association with adiposity, long-standing diabetes appears to protect against both high- and low-grade PCa. This apparent paradox may be due to the fact that long-standing diabetes is associated with insulin resistance. Insulin is a potent mitogenic and anti-apoptotic factor, which has potent growth-stimulatory effects on the prostate, and DNA polymorphisms in the insulin gene may be associated with increased PCa risk (Hsing et al. 2007). Thus, progressive insulin resistance and $\beta$-cell failure with insulin depletion occurring with increasing duration of diabetes may limit insulin actions and hence protect against PCa. Different degrees of insulin sensitivity may also in part explain the confusing observational data linking the MetS to PCa discussed above where combining multiple components of the syndrome - which individually may have opposing effects on PCa risk - could obscure these independent interactions of individual metabolic factors with $\mathrm{PCa}$ risk. This insulin-PCa association however remains speculative, as data supporting a direct causal role of insulin in prostate carcinogenesis remain limited. The relationship of insulin with PCa is further confounded by, among others, complex interactions with adiposityassociated inflammation and decreases in circulating androgens, which will be discussed further below.

Consistent with a role for insulin in promoting PCa are findings from a prospective case-cohort study in non-diabetic men suggesting that both elevated insulin concentrations and increased HOMA-IR values, but not glucose levels, predicted increased $\mathrm{PCa}$ risk (Albanes et al. 2009). Moreover, in the placebo arm of the finasteride PCa prevention trial, higher baseline C-peptide levels were associated with a nearly twofold increased risk of high-grade $\mathrm{PCa}$ (multivariateadjusted OR 1.88; 95\% CI, 1.19-2.97; Neuhouser et al. 2010). Similarly, a prospective analysis from the Physicians' Health Study showed that baseline high C-peptide concentrations predisposed men with a subsequent diagnosis of PCa to an increased risk of $\mathrm{PCa}$ death that was independent of and additive to baseline BMI (Ma et al. 2008). In an LNCaP xenograft model, mice fed a high fat diet showed significantly increased serum insulin levels and experienced accelerated $\mathrm{PCa}$ growth compared to mice receiving a low fat diet, and serum from mice receiving the high fat diet was more mitogenic for LNCaP cells in vitro (Venkateswaran et al. 2007). 
Insulin stimulates IGF1 secretion, which has been shown to promote growth of primary prostate cell cultures and of human PCa cell lines in vitro (De Nunzio et al. 2011). Transgenic mice overexpressing human IGF1 in basal epithelial cells of the prostate develop prostate carcinoma at a high rate (50\%) (DiGiovanni et al. 2000), and mice with global or liver-specific inactivation of IGF1 show reduced prostate size and reduced androgen-dependent prostate growth (Svensson et al. 2008). Indeed, a meta-analysis of 42 observational studies confirmed that raised circulating IGF1 levels were significantly associated with PCa risk (OR 1.21; 95\% CI, 1.07-1.36), with weak evidence that this association was stronger for advanced PCa (Rowlands et al. 2009). Similarly, a pooled analysis of individual patient data from 12 prospective studies showed that greater serum IGF1 concentrations were associated with a greater subsequent risk of PCa (OR 1.38; 95\% CI, 1.19-1.60), although in this study, the association was somewhat stronger for low-grade disease (Roddam et al. 2008b). Associations of other IGFs or their binding proteins with PCa were inconsistent (Roddam et al. 2008b, Rowlands et al. 2009). Limitations of individual studies analysed in both papers (Roddam et al. 2008b, Rowlands et al. 2009) included absence of information regarding $\mathrm{PCa}$ stage, PSA screening history and reliance on single serum samples.

\section{Adipokines and inflammation}

In addition to insulin and IGF1, visceral obesity may mediate effects on PCa via secretion of adipokines and proinflammatory cytokines. While leptin promotes PCa cell proliferation and inhibits apoptosis in vitro (Onuma et al. 2003), epidemiological evidence linking leptin levels to $\mathrm{PCa}$ in men has been inconsistent (Hsing et al. 2007, Li et al. 2010, Neuhouser et al. 2010). Adiponectin is an insulin sensitising adipokine which is inversely correlated with amount of visceral fat. Interestingly, in a prospective analysis from the Physicians' Health Study, men with higher adiponectin levels had a lower risk of developing high grade or lethal $\mathrm{PCa}$, and this risk remained independent of $\mathrm{BMI}$ and C-peptide levels (HR 0.39; 95\% CI, 0.17-0.85; Li et al. 2010). Further support that adiponectin may play a protective role - rather than simply serving as a surrogate of insulin sensitivity - stems from observations that adiponectin inhibits tumour-induced angiogenesis (Brakenhielm et al. 2004) and PCa cell growth (Bub et al. 2006) in vitro. In addition, adiponectin gene polymorphisms have recently been associated with PCa risk, serum adiponectin levels and insulin receptor or IGF1 receptor expression in prostate tumour specimens, although there was no association by tumour grade or clinical stage (Dhillon et al. 2011).

The chronic proinflammatory state associated with obesity and the MetS may also contribute to $\mathrm{PCa}$ development and progression. Proinflammatory cytokines known to be elevated in the MetS such as tumour necrosis factor $\alpha$ (TNFa), interleukin (IL) 6 and IL8 have been associated with increased PCa risk and stage (Hsing et al. 2007). These cytokines stimulate the nuclear factor kappaB (NF-kB) pathway, which in turn has been linked to prostate carcinogenesis. NF-kB activation is constitutive in $\mathrm{PCa}$ cell lines, directly related to the extent of lymph node invasion in radical prostatectomy specimens, and may be involved in androgen-independent PCa progression (Jin et al. 2008, Gorbachinsky et al. 2010). Elegant experiments in mice with a targeted deletion of the NF-kB stimulatory kinase IKK- $\alpha$ have revealed an essential requirement for NF-kB activation in the emergence of castrate-resistant PCa (Ammirante et al. 2010). One upstream activator of the proinflammatory and antiapoptotic NF-kB pathway is the endoplasmatic reticulum (ER) chaperone protein GRP78. The presence of GRP78 activating auto-antibodies in patient sera is associated with a poor $\mathrm{PCa}$ prognosis (Misra et al. 2010). Interestingly, treatment of PCa cell lines with an antibody that inhibits auto-antibody induced GRP78 activation inhibits NF-kB activation in vitro, providing preliminary evidence for a strategy for anti-PCa therapy (Misra et al. 2010).

\section{Nutrients and fatty acids}

In population-based studies, a diet high in animal fat and low in vegetables has been associated with increased PCa risk, unfavourable prognosis and relapse after treatment for localised PCa (Chan et al. 2005). PCa cells express high levels of fatty acid synthase from which they derive fatty acids for membrane biosynthesis to sustain cell proliferation. In addition, there is evidence that $\mathrm{PCa}$-associated lipogenesis may disturb cell surface cilium formation leading to impaired environmental sensing, aberrant signalling and disruption of cellular architecture (Willemarck et al. 2010). A genome-wide gene expression analysis has found the lipogenic gene ELOVL7 to be overexpressed in $\mathrm{PCa}$, and knockdown of ELOVL7 in the PCa cell lines LNCaP and 22RV1 markedly reduced their growth and androgen synthesis in vitro (Tamura et al. 2009). The fatty acid arachidonic acid has also been shown to stimulate de novo androgen biosynthesis in steroid-starved PCa cells, which may in turn trigger 
AR reactivation in castrate-resistant $\mathrm{PCa}$ (Locke et al. 2010). In addition, saturated fatty acids may promote prostate carcinogenesis by increasing IGF1 signalling, increasing ER stress and disturbing activation of the innate immune system (Lu \& Archer 2010).

Some but not all epidemiological studies show that an increased intake of omega-3 (n-3) polyunsaturated fatty acids (PUFA) decreases, whereas increased consumption of $n-6$ PUFA increases PCa risk (Astorg 2004, Heinze \& Actis 2012). In addition, there is experimental evidence that $n-3$ PUFA suppresses, whereas $n-6$ PUFA promotes prostate carcinogenesis. For example, increasing the dietary $n-3 / n-6$ PUFA ratio also increased this ratio in tumour membranes and reduced vascular endothelial growth factor expression, cell proliferation and tumour volume (Kobayashi et al. 2006). Xenograft studies with androgen-dependent (CWR22) and androgen-independent (CWR22R) + human PCa cells have suggested that dietary changes that increased tumour $n$-3 PUFA content enhanced the response to androgen-ablative therapy (McEntee et al. 2008). Treatment of PCa cell lines with the $n$-3 PUFA docosahexaenoic acid (DHA) reduced NF-kB activation and cell survival in response to oxidative stress, suggesting that DHA sensitises PCa cells to growth arrest through attenuation of the NF-kB survival pathway (Cavazos et al. 2011). Although there is to date no controlled evidence that dietary interventions modulate $\mathrm{PCa}$ risk and progression, clinical trials using DHA in the prevention and treatment of $\mathrm{PCa}$ are underway (http://clinicaltrials.gov).

\section{Effects of sex steroids on PCa}

Since Huggins Nobel-Prize winning observations (Huggins \& Hodges 1941), it has been known that androgens are critical for normal prostate development and function, as well as for PCa growth and progression. For example, men with $5-\alpha$ reductase deficiency (the enzyme that converts testosterone into dihydrotestosterone (DHT), the main intraprostatic androgen) are protected against the development of PCa (Imperato-McGinley et al. 1974). However, the role of 5- $\alpha$ reductase inhibitors in the prevention of $\mathrm{PCa}$ remains under debate. ADT further discussed below has long been the mainstay in the treatment of metastatic PCa. DNA sequences associated with PCa risk identified in GWAS are significantly enriched in androgen receptor (AR)-binding sites, as well as in FoxA1-binding sites, an AR co-activator required for AR binding to enhancers in multiple AR-target genes (Lu et al. 2011). While a recent meta-analysis has concluded that an increased number of AR CAG repeats, which leads to a biologically less active AR, may be associated with protection against $\mathrm{PCa}$ in men older than 45 years ( $\mathrm{Gu}$ et al. 2011), the association between AR CAG repeat length and PCa risk remains controversial. A germline mutation in the homeobox transcription factor $H O X B 13$ gene has recently been associated with a 20-fold increased risk of familial $\mathrm{PCa}$, and $H O X B 13$ physically interacts with the AR (Ewing et al. 2012).

Although it is well accepted that PCa is an androgendependent malignancy, whether androgens are involved in the initiation of PCa remains controversial. The association of testosterone and other sex steroids with PCa risk has been analysed in multiple observational studies. The most definitive evidence comes from a collaborative analysis of 18 prospective studies including 3886 men with incident $\mathrm{PCa}$ and 6438 control subjects. In this study, no associations were found between the risk of $\mathrm{PCa}$ and serum concentrations of total testosterone, calculated free testosterone, DHT, oestradiol, DHEAS, or indeed any other sex steroid tested (Roddam et al. 2008a).

Consistent with these observational studies suggesting a lack of a role of circulating sex steroids in PCa initiation are findings from trials of testosterone therapy. While regular rectal examinations and PSA monitoring during testosterone therapy is recommended (Bhasin et al. 2010), several meta-analyses failed to show an increased risk of $\mathrm{PCa}$ with testosterone therapy (Calof et al. 2005, FernandezBalsells et al. 2010), despite an increased rate of prostate biopsies in one analysis (Calof et al. 2005). However, studies included in these meta-analyses have been limited by small numbers, low quality and short duration. Thus, in the absence of an adequately designed and powered RCT, the PCa risk of testosterone therapy remains unknown. It has been estimated that 6000 men would need to be randomised to testosterone or placebo for 5 years to determine if testosterone therapy increases the risk of PCa by $30 \%$ (Liverman \& Blazer 2004). Current guidelines advise avoidance of testosterone therapy in patients with $\mathrm{PCa}$, a palpable nodule or induration or a PSA of $>4 \mathrm{ng} / \mathrm{ml}$ (>3 ng/ml in high-risk men) (Bhasin et al. 2010). Although some have suggested that testosterone therapy can be considered in selected hypogonadal men with previously treated $\mathrm{PCa}$, the safety of this approach is currently based on anecdotal evidence, and remains a matter of debate (Landau et al. 2012).

It is well recognised that relating a serum testosterone level to a clinical phenotype is an oversimplification, given that circulating testosterone levels, whether free or total (Ly et al. 2010), are 
unlikely to accurately reflect androgen action at the tissue level. Testosterone action is modulated by AR polymorphisms and transcriptional cofactors, and local androgen synthesis and inactivation may not be reflected in circulating testosterone levels. DHT, the principal prostatic androgen, has a tenfold higher activity at the AR compared to testosterone, and circulating DHT concentrations in serum are tenfold lower than testosterone, while the opposite is true for intraprostatic DHT concentrations (Marks et al. 2008). Whether variations in intraprostatic androgens which may have little correlation with circulating androgens affect prostate carcinogenesis is more difficult to study. In a small (44 men) short-term (6 months) RCT of testosterone therapy, there was no difference in intraprostatic androgen levels, prostate histology or gene expression in men given testosterone compared to placebo (Marks et al. 2006). In a 4-week RCT of DHT vs placebo in $31 \mathrm{men}$, despite robust increases in circulating DHT in the DHT-treated group, there was again no difference in intraprostatic DHT or testosterone concentrations, epithelial cell proliferation or AR-regulated gene expression (Page et al. 2011). In addition, a larger RCT of DHT therapy of 2 year duration in 114 healthy men showed no effect on prostate volume (measured by ultrasonography) or PSA levels (Idan et al. 2010).

The lack of correlation of circulating or intraprostatic androgens with PCa risk in preliminary studies, combined with the lack of evidence to date that testosterone therapy increases this risk, has led to the proposal of the so-called 'saturation model' of the AR (Morgentaler \& Traish 2009). According to this model, there is a limited ability of the prostate to respond to increased androgens because of a finite capacity of the AR to bind androgens. Therefore, the androgenic response of the prostate is postulated to be sensitive to changes in circulating androgens only at low androgen concentrations. An increase of circulating androgens above a certain threshold will saturate the AR, so that the prostate will no longer respond to further increases in circulating levels of androgens above this saturation point. Conversely, below a certain lower androgen threshold, the 'castrate' level, the androgenic response will decrease, consistent with the therapeutic effect of ADT on established PCa (Morgentaler \& Traish 2009, Goldenberg et al. 2011). While there is experimental evidence to support such a model reviewed elsewhere (Morgentaler \& Traish 2009, Goldenberg et al. 2011), the saturation model is not yet proven and more research is needed.

Interestingly, some evidence suggests that low circulating testosterone levels may be a risk factor for PCa aggressiveness. For example, several, but not all (Salonia et al. 2011) cross-sectional, studies have suggested that low testosterone levels at the time of $\mathrm{PCa}$ diagnosis is associated with more aggressive disease, for review see Goldenberg et al. (2011) and Morgentaler (2011). Low testosterone levels have also been linked to more advanced PCa stages, and more aggressive phenotypes in radical retropubic prostatectomy specimens (Goldenberg et al. 2011).

\section{Relationship between sex steroids and diabetes}

In part, the contradictory literature regarding the relationship between circulating androgens and $\mathrm{PCa}$ risk may relate to the fact that obesity and diabetes, which themselves may increase or decrease PCa risk or aggressiveness respectively, have complex interactions with circulating sex steroid levels (Grossmann et al. 2010). Several large studies have shown that 30-50\% of ageing, obese men with type 2 diabetes have circulating testosterone levels below the reference range derived from healthy young men (Dhindsa et al. 2004, Kapoor et al. 2007, Grossmann et al. 2008). A meta-analysis of cross-sectional case-control studies showed that men with diabetes had significantly lower total testosterone compared to men without diabetes, even after adjustment for age and crude measures of body fat (mean pooled difference 1-0.61 nmol/1; 95\% CI, -2.56 to $-0.65 \mathrm{nmol} / \mathrm{l}$ ) (Ding et al. 2006). In addition, in prospective studies, men with higher testosterone levels had a $42 \%$ lower risk of future diabetes (Ding et al. 2006), although the relationship between low testosterone and diabetes may be partially explained by several modifiable risk factors (Atlantis et al. 2009, 2011). Similar to diabetes, the presence of the MetS is also associated with a moderate, $2-3 \mathrm{nmol} / \mathrm{l}$ decrease in total testosterone in population-based studies, reviewed in Grossmann (2011). The lower testosterone levels in men with diabetes or the MetS is driven, at least in part, by increased visceral adiposity and insulin resistance, via a complex bi-directional relationship (Araujo \& Wittert 2011). Visceral adiposity promotes a lowering of testosterone, and low testosterone predisposes to central weight gain, creating a viscous circle promoting insulin resistance (Fig. 2; Grossmann et al. 2010). Indeed, testosterone therapy promotes metabolically favourable changes in body composition (Wittert et al. 2003) associated with moderate decreases in insulin resistance (Grossmann 2011), whereas, conversely ADT given to men with $\mathrm{PCa}$ leads to visceral fat gain and increased insulin resistance (Hamilton et al. 2011). In addition, weight loss can lead to substantial increases in testosterone 


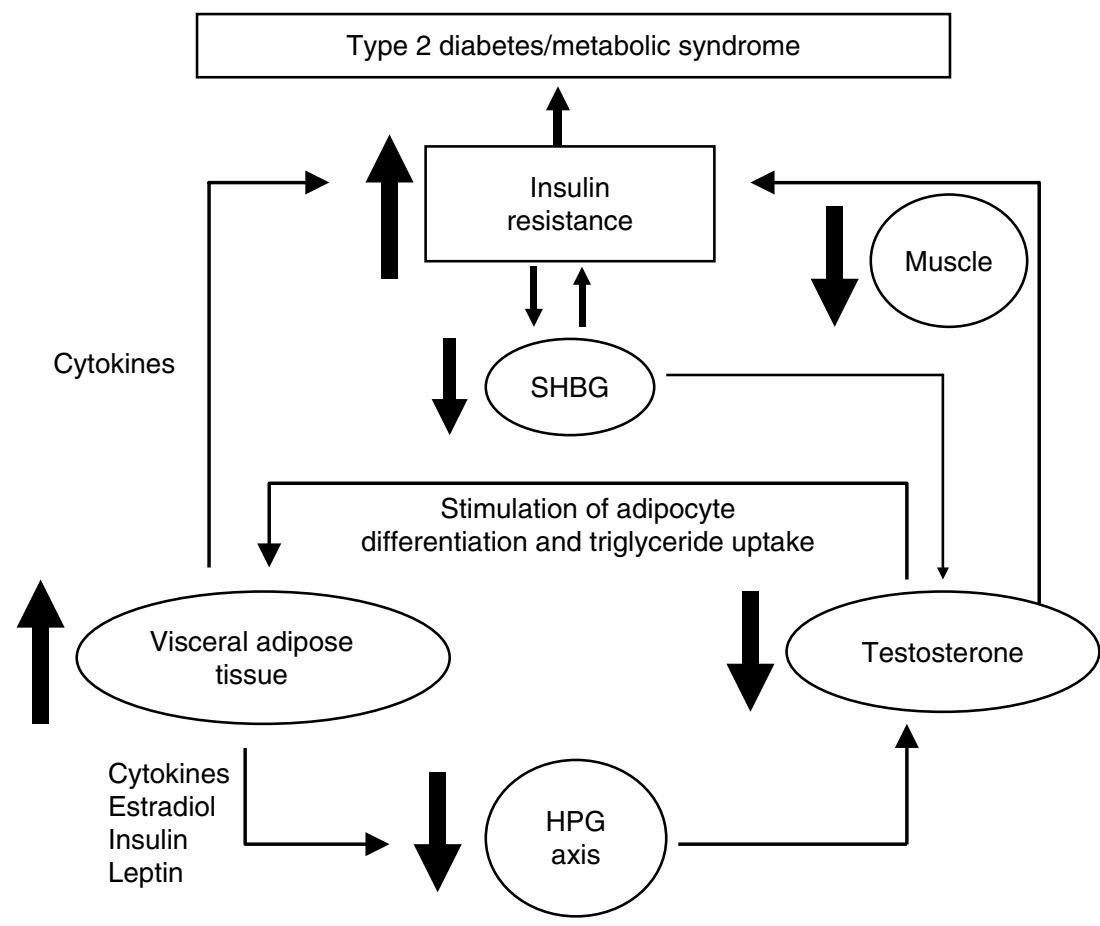

Figure 2 Bi-directional relationship between visceral fat and testosterone. A self-perpetuating cycle promoting insulin resistance. HPG, hypothalamo-pituitary-gonadal axis. (Adapted from Grossmann et al. (2010)).

levels, especially in morbidly obese men (Khoo et al. 2010), and this increase in testosterone is proportional to the amount of weight lost (Grossmann 2011). Thus, testosterone has complex interactions not only with prostate biology, but also direct relationships with $\mathrm{PCa}$ metabolic risk factors such as diabetes, obesity and the MetS. This mutual interdependence further complicates the dissection of the relative roles of androgens and metabolic factors in prostate carcinogenesis.

Testosterone is not only a hormone, but also a prohormone and at least some of its actions in men occur as a consequence of its aromatisation to oestradiol. Characterisation of the role of oestradiol in prostate carcinogenesis is made difficult by its close association with adiposity and the challenges in accurately quantifying the very low circulating oestradiol levels in men. In addition, circulating oestradiol is positively associated with diabetes even after adjustment for fat mass and distribution (Vikan et al. 2010). In prostate epithelial cells, oestradiol activation of the oestrogen receptor (ER) $\alpha$ aberrantly stimulates cell proliferation and is pro-inflammatory, whereas oestradiol action through ER $\beta$ is anti-proliferative and anti-inflammatory (Risbridger et al. 2010). There is evidence that oestradiol is involved, either by itself or in synergy with androgens, in PCa pathogenesis. For example, the circulating oestradiol/testosterone ratio is higher in older men, and in African American men, who are at higher risk of $\mathrm{PCa}$, but lower in less susceptible Japanese men (Ho et al. 2011). There is evidence that intraprostatic activation of aromatase increases during prostate carcinogenesis, and animal models support the suggestion that oestrogens, alone or in concert with androgens, are potent inducers of aberrant growth and neoplastic transformation in the prostate (Risbridger et al. 2010, Ho et al. 2011).

\section{Metabolic side effects of ADT}

ADT is the standard therapy for palliation of metastatic $\mathrm{PCa}$ and improves mortality as adjuvant therapy for locally advanced or high-risk localised tumours treated with radiotherapy (Shahinian 2011). Use of ADT doubled over the course of the 1990 and extended to settings where mortality benefit is unproven, such as primary treatment of asymptomatic disease or of biochemical (PSA) recurrence after prior prostatectomy or radiotherapy (Shahinian 2011). Given the overall favourable prognosis of $\mathrm{PCa}$ and the high prevalence of underlying cardiovascular disease and osteoporosis in older men, even a modest increase in ADT-associated cardiovascular or fracture risk may be 
important, especially in settings where the benefit of ADT on PCa mortality has not been proven (Grossmann \& Zajac 2011a). Given that cardiovascular events are among the most common causes of death in men with PCa (Satariano et al. 1998), it is of concern that several retrospective studies have associated ADT with increased risk of diabetes and possibly, cardiovascular events, for review, see Grossmann \& Zajac (2011b). While retrospective studies are subject to bias and confounding factors, findings have, at least with respect to diabetes, been consistent. They are also biologically plausible, because prospective studies have shown that ADT leads to metabolically unfavourable changes in body composition with increased total and visceral fat, loss of muscle mass and associated increases in insulin resistance, itself an independent cardiovascular risk factor (Smith et al. 2001, Hamilton et al. 2011). This prompted the US Food and Drug Administration to issue a safety warning in October 2010, requiring labelling on GnRH agonists warning about and 'increased risk of diabetes and certain cardiovascular diseases'. However, in a recent metaanalysis of RCTs in unfavourable-risk PCa, ADT was not associated with an increased risk of cardiovascular death, but was associated with a lower risk of $\mathrm{PCa}-$ specific and all-cause mortality (Nguyen et al. 2011). While further study is necessary to better define the risk benefit ratio of $\mathrm{ADT}$, these findings provide reassurance regarding the use of ADT in appropriately selected PCa patients. In addition, evidence-based guidelines are available to monitor and manage metabolic health in patients with $\mathrm{PCa}$ receiving ADT in order to minimise ADT-related adverse outcomes (Grossmann et al. 2011).

\section{Summary and conclusions}

While the strength of the associations between metabolic conditions and $\mathrm{PCa}$ risk and disease progression in population-based studies is modest, there is a consistent picture of obesity being associated with aggressive PCa and worse cancer-specific outcome. Increased insulin and IGF1 signalling, inflammation and obesity-associated changes in sex steroid levels, and disturbances in fatty acid metabolism may all play a role in prostate carcinogenesis (Fig. 3). Indeed, testosterone and oestradiol have complex relationships not only with prostate biology, but also with metabolic disorders. In contrast, the protective effect of long-standing diabetes may be explained by associated $\beta$-cell exhaustion with insulin depletion. However, evidence to date is largely observational and therefore, the causality of such associations has not yet been proven. In addition, some of these associations may be overestimated because of competing risk, given the long latency of PCa. On the other hand, because of the interplay between sex steroids and metabolic conditions which individually may either promote or suppress prostate carcinogenesis, isolating their respective contributions to $\mathrm{PCa}$ development and promotion has proven difficult. In light of the high and increasing global prevalence of $\mathrm{PCa}$ and of metabolic conditions as life expectancy and affluence increases worldwide, this is clearly a high priority for further research. Future adequately powered prospective studies should incorporate accurate measures of sex steroids by HPLC/mass spectrometry, of regional (especially visceral) obesity, of glucose metabolism, and of PCa grade and stage. The available data are sufficiently mature to warrant controlled trials to test

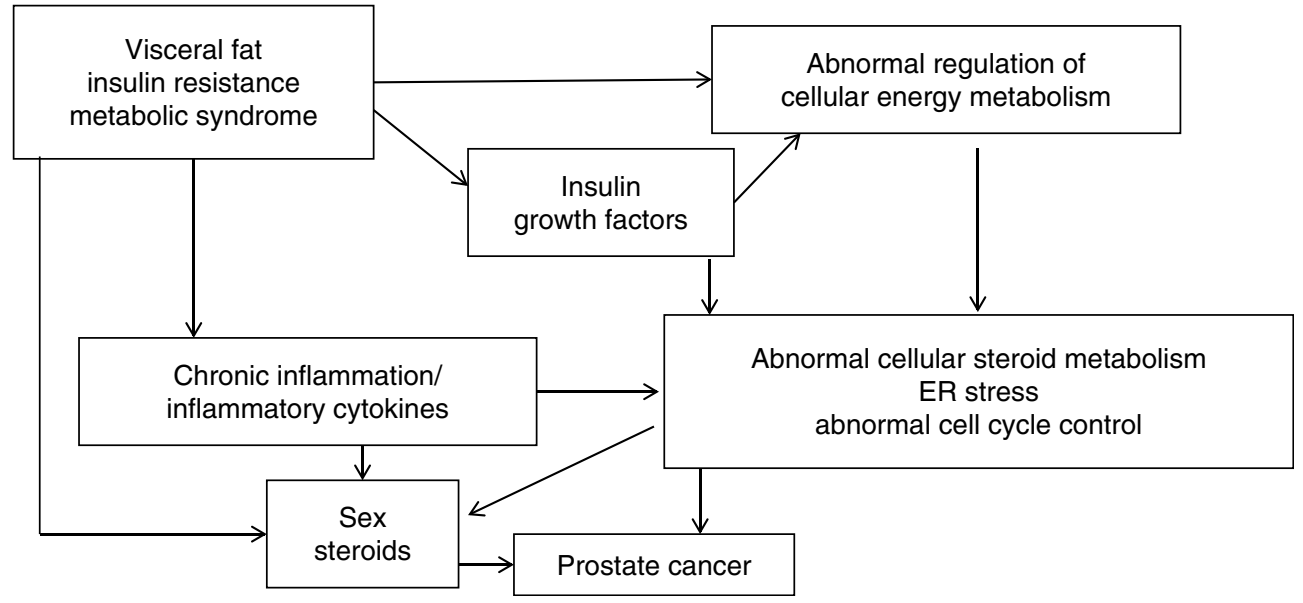

Figure 3 Metabolic factors, sex steroids and prostate cancer. 
the hypothesis that weight loss, either by diet or exercise, or medical therapies that reduce insulin excess may decrease PCa risk or disease progression. Institution of healthy lifestyle to promote weight loss is unlikely to have negative effects on prostate health and has multiple other health benefits, including moderate increases in endogenous testosterone levels. Since ADT may increase risk of diabetes and cardiovascular events, this therapy should only be used in settings of proven benefit. Men receiving ADT should be routinely monitored to minimise ADT-associated adverse events.

\section{Declaration of interest}

The authors declare that there is no conflict of interest that could be perceived as prejudicing the impartiality of the research reported.

\section{Funding}

M Grossmann was supported by grants from the National Health and Medical Research Council of Australia (grant numbers 1006407, 1024139).

\section{Acknowledgements}

We are most grateful to Professor Wayne Tilley for his helpful comments.

\section{References}

Albanes D, Weinstein SJ, Wright ME, Mannisto S, Limburg PJ, Snyder K \& Virtamo J 2009 Serum insulin, glucose, indices of insulin resistance, and risk of prostate cancer. Journal of the National Cancer Institute 101 1272-1279. (doi:10.1093/jnci/djp260)

Ammirante M, Luo JL, Grivennikov S, Nedospasov S \& Karin M 2010 B-cell-derived lymphotoxin promotes castration-resistant prostate cancer. Nature 464 302-305. (doi:10.1038/nature08782)

Araujo AB \& Wittert GA 2011 Endocrinology of the aging male. Best Practice \& Research. Clinical Endocrinology \& Metabolism 25 303-319. (doi:10.1016/j.beem.2010.11. 004)

Astorg P 2004 Dietary n-6 and n-3 polyunsaturated fatty acids and prostate cancer risk: a review of epidemiological and experimental evidence. Cancer Causes \& Control 15 367-386. (doi:10.1023/B:CACO.0000027498. 94238.a3)

Atlantis E, Martin SA, Haren MT, O'Loughlin PD, Taylor AW, Anand-Ivell R, Ivell R \& Wittert GA 2009 Demographic, physical and lifestyle factors associated with androgen status: the Florey Adelaide Male Ageing Study (FAMAS). Clinical Endocrinology 71 261-272. (doi:10.1111/j.13652265.2008.03463.x)
Atlantis E, Lange K, Martin S, Haren MT, Taylor A, O’Loughlin PD, Marshall V \& Wittert GA 2011 Testosterone and modifiable risk factors associated with diabetes in men. Maturitas 68 279-285. (doi:10.1016/ j.maturitas.2010.12.007)

Bhasin S, Cunningham GR, Hayes FJ, Matsumoto AM, Snyder PJ, Swerdloff RS \& Montori VM 2010 Testosterone therapy in men with androgen deficiency syndromes: an Endocrine Society clinical practice guideline. Journal of Clinical Endocrinology and Metabolism 95 2536-2559. (doi:10.1210/jc.2009-2354)

Brakenhielm E, Veitonmaki N, Cao R, Kihara S, Matsuzawa Y, Zhivotovsky B, Funahashi T \& Cao Y 2004 Adiponectin-induced antiangiogenesis and antitumor activity involve caspase-mediated endothelial cell apoptosis. PNAS 101 2476-2481. (doi:10.1073/ pnas.0308671100)

Bub JD, Miyazaki T \& Iwamoto Y 2006 Adiponectin as a growth inhibitor in prostate cancer cells. Biochemical and Biophysical Research Communications 340 1158-1166. (doi:10.1016/j.bbrc.2005.12.103)

Calof OM, Singh AB, Lee ML, Kenny AM, Urban RJ, Tenover JL \& Bhasin S 2005 Adverse events associated with testosterone replacement in middle-aged and older men: a meta-analysis of randomized, placebo-controlled trials. Journals of Gerontology. Series A, Biological Sciences and Medical Sciences 60 1451-1457. (doi:10.1093/gerona/60.11.1451)

Cavazos DA, Price RS, Apte SS \& deGraffenried LA 2011 Docosahexaenoic acid selectively induces human prostate cancer cell sensitivity to oxidative stress through modulation of NF-kappaB. Prostate 71 1420-1428. (doi:10.1002/pros.21359)

Chan JM, Gann PH \& Giovannucci EL 2005 Role of diet in prostate cancer development and progression. Journal of Clinical Oncology 23 8152-8160. (doi:10.1200/JCO. 2005.03.1492)

De Nunzio C, Aronson W, Freedland SJ, Giovannucci E \& Parsons JK 2011 The correlation between metabolic syndrome and prostatic diseases. European Urology 61 560-570. (doi:10.1016/j.eururo.2011.11.013)

Dhillon PK, Penney KL, Schumacher F, Rider JR, Sesso HD, Pollak M, Fiorentino M, Finn S, Loda M, Rifai N et al. 2011 Common polymorphisms in the adiponectin and its receptor genes, adiponectin levels and the risk of prostate cancer. Cancer Epidemiology, Biomarkers \& Prevention 20 2618-2627. (doi:10.1158/1055-9965.EPI-11-0434)

Dhindsa S, Prabhakar S, Sethi M, Bandyopadhyay A, Chaudhuri A \& Dandona P 2004 Frequent occurrence of hypogonadotropic hypogonadism in type 2 diabetes. Journal of Clinical Endocrinology and Metabolism 89 5462-5468. (doi:10.1210/jc.2004-0804)

DiGiovanni J, Kiguchi K, Frijhoff A, Wilker E, Bol DK, Beltran L, Moats S, Ramirez A, Jorcano J \& Conti C 2000 Deregulated expression of insulin-like growth factor 1 in prostate epithelium leads to neoplasia in transgenic mice. PNAS 97 3455-3460. (doi:10.1073/pnas.97.7.3455) 
Ding EL, Song Y, Malik VS \& Liu S 2006 Sex differences of endogenous sex hormones and risk of type 2 diabetes: a systematic review and meta-analysis. Journal of the American Medical Association 295 1288-1299. (doi:10.1001/jama.295.11.1288)

Elliott KS, Zeggini E, McCarthy MI, Gudmundsson J, Sulem P, Stacey SN, Thorlacius S, Amundadottir L, Gronberg H, $\mathrm{Xu} \mathrm{J}$ et al. 2010 Evaluation of association of HNF1B variants with diverse cancers: collaborative analysis of data from 19 genome-wide association studies. PLOS ONE 5 e10858. (doi:10.1371/journal.pone.0010858)

Ewing CM, Ray AM, Lange EM, Zuhlke KA, Robbins CM, Tembe WD, Wiley KE, Isaacs SD, Johng D, Wang Y et al. 2012 Germline mutations in HOXB13 and prostatecancer risk. New England Journal of Medicine 366 141-149. (doi:10.1056/NEJMoa1110000)

Fernandez-Balsells MM, Murad MH, Lane M, Lampropulos JF, Albuquerque F, Mullan RJ, Agrwal N, Elamin MB, Gallegos-Orozco JF, Wang AT et al. 2010 Clinical review 1: adverse effects of testosterone therapy in adult men: a systematic review and meta-analysis. Journal of Clinical Endocrinology and Metabolism 95 2560-2575. (doi:10.1210/jc.2009-2575)

Giovannucci E, Rimm EB, Stampfer MJ, Colditz GA \& Willett WC 1998 Diabetes mellitus and risk of prostate cancer (United States). Cancer Causes \& Control 9 3-9. (doi:10.1023/A:1008822917449)

Goldenberg SL, Koupparis A \& Robinson ME 2011 Differing levels of testosterone and the prostate: a physiological interplay. Nature Reviews. Urology 8 365-377. (doi:10.1038/nrurol.2011.79)

Gong Z, Neuhouser ML, Goodman PJ, Albanes D, Chi C, Hsing AW, Lippman SM, Platz EA, Pollak MN, Thompson IM et al. 2006 Obesity, diabetes, and risk of prostate cancer: results from the prostate cancer prevention trial. Cancer Epidemiology, Biomarkers \& Prevention 15 1977-1983. (doi:10.1158/1055-9965. EPI-06-0477)

Gorbachinsky I, Akpinar H \& Assimos DG 2010 Metabolic syndrome and urologic diseases. Reviews in Urology 12 e157-e180.

Grossmann M 2011 Low testosterone in men with type 2 diabetes: significance and treatment. Journal of Clinical Endocrinology and Metabolism 96 2341-2353. (doi:10.1210/jc.2011-0118)

Grossmann M \& Zajac JD 2011a Androgen deprivation therapy in men with prostate cancer: how should the side effects be monitored and treated? Clinical Endocrinology 74 289-293. (doi:10.1111/j.1365-2265.2010.03939.x)

Grossmann M \& Zajac JD 2011b Management of side effects of androgen deprivation therapy. Endocrinology and Metabolism Clinics of North America 40 655-671, x. (doi:10.1016/j.ecl.2011.05.004)

Grossmann M, Thomas MC, Panagiotopoulos S, Sharpe K, Macisaac RJ, Clarke S, Zajac JD \& Jerums G 2008 Low testosterone levels are common and associated with insulin resistance in men with diabetes. Journal of Clinical Endocrinology and Metabolism 93 1834-1840. (doi:10.1210/jc.2007-2177)

Grossmann M, Gianatti EJ \& Zajac JD 2010 Testosterone and type 2 diabetes. Current Opinion in Endocrinology, Diabetes, and Obesity 17 247-256. (doi:10.1097/MED. Ob013e32833919cf)

Grossmann M, Hamilton EJ, Gilfillan C, Bolton D, Joon DL \& Zajac JD 2011 Bone and metabolic health in patients with non-metastatic prostate cancer who are receiving androgen deprivation therapy. Medical Journal of Australia 194 301-306.

Grundmark B, Garmo H, Loda M, Busch C, Holmberg L \& Zethelius B 2010 The metabolic syndrome and the risk of prostate cancer under competing risks of death from other causes. Cancer Epidemiology, Biomarkers \& Prevention 19 2088-2096. (doi:10.1158/1055-9965.EPI-10-0112)

Gu M, Dong X, Zhang X \& Niu W 2011 The CAG repeat polymorphism of androgen receptor gene and prostate cancer: a meta-analysis. Molecular Biology Reports 39 2615-2624. (doi:10.1007/s11033-011-1014-9)

Gudmundsson J, Sulem P, Steinthorsdottir V, Bergthorsson JT, Thorleifsson G, Manolescu A, Rafnar T, Gudbjartsson D, Agnarsson BA, Baker A et al. 2007 Two variants on chromosome 17 confer prostate cancer risk, and the one in TCF2 protects against type 2 diabetes. Nature Genetics 39 977-983. (doi:10.1038/ng2062)

Hamilton EJ, Gianatti E, Strauss BJ, Wentworth J, Lim-Joon D, Bolton D, Zajac JD \& Grossmann M 2011 Increase in visceral and subcutaneous abdominal fat in men with prostate cancer treated with androgen deprivation therapy. Clinical Endocrinology 74 377-383. (doi:10.1111/j.1365-2265.2010.03942.x)

Heinze VM \& Actis AB 2012 Dietary conjugated linoleic acid and long-chain $n-3$ fatty acids in mammary and prostate cancer protection: a review. International Journal of Food Sciences and Nutrition 63 66-78. (doi:10.3109/09637486.2011.598849)

Ho SM, Lee MT, Lam HM \& Leung YK 2011 Estrogens and prostate cancer: etiology, mediators, prevention, and management. Endocrinology and Metabolism Clinics of North America 40 591-614, ix. (doi:10.1016/j.ecl.2011. 05.002)

Hsing AW, Sakoda LC \& Chua S Jr 2007 Obesity, metabolic syndrome, and prostate cancer. American Journal of Clinical Nutrition 86 s843-s857.

Huggins C \& Hodges CV 1941 Studies on prostatic cancer: I. The effects of castration, of estrogen and of androgen injection on serum phosphatases in metastatic carcinoma of the prostate. Cancer Research 1 293-297.

Idan A, Griffiths KA, Harwood DT, Seibel MJ, Turner L, Conway AJ \& Handelsman DJ 2010 Long-term effects of dihydrotestosterone treatment on prostate growth in healthy, middle-aged men without prostate disease: a randomized, placebo-controlled trial. Annals of Internal Medicine 153 621-632. 
Imperato-McGinley J, Guerrero L, Gautier T \& Peterson RE 1974 Steroid $5 \alpha$-reductase deficiency in man: an inherited form of male pseudohermaphroditism. Science $\mathbf{1 8 6}$ 1213-1215. (doi:10.1126/science.186.4170.1213)

Jemal A, Siegel R, Xu J \& Ward E 2010 Cancer statistics, 2010. CA: A Cancer Journal for Clinicians 60 277-300. (doi:10.3322/caac.20073)

Jin RJ, Lho Y, Connelly L, Wang Y, Yu X, Saint Jean L, Case TC, Ellwood-Yen K, Sawyers CL, Bhowmick NA et al. 2008 The nuclear factor-kappaB pathway controls the progression of prostate cancer to androgen-independent growth. Cancer Research 68 6762-6769. (doi:10.1158/ 0008-5472.CAN-08-0107)

Kapoor D, Aldred H, Clark S, Channer KS \& Jones TH 2007 Clinical and biochemical assessment of hypogonadism in men with type 2 diabetes: correlations with bioavailable testosterone and visceral adiposity. Diabetes Care 30 911-917. (doi:10.2337/dc06-1426)

Kasper JS \& Giovannucci E 2006 A meta-analysis of diabetes mellitus and the risk of prostate cancer. Cancer Epidemiology, Biomarkers \& Prevention 15 2056-2062. (doi:10.1158/1055-9965.EPI-06-0410)

Kasper JS, Liu Y \& Giovannucci E 2009 Diabetes mellitus and risk of prostate cancer in the health professionals follow-up study. International Journal of Cancer 124 1398-1403. (doi:10.1002/ijc.24044)

Khoo J, Piantadosi C, Worthley S \& Wittert GA 2010 Effects of a low-energy diet on sexual function and lower urinary tract symptoms in obese men. International Journal of Obesity 34 1396-1403. (doi:10.1038/ijo.2010.76)

Kim ST, Cheng Y, Hsu FC, Jin T, Kader AK, Zheng SL, Isaacs WB, Xu J \& Sun J 2010 Prostate cancer riskassociated variants reported from genome-wide association studies: meta-analysis and their contribution to genetic variation. Prostate 70 1729-1738. (doi:10.1002/ pros.21189)

Kobayashi N, Barnard RJ, Henning SM, Elashoff D, Reddy ST, Cohen P, Leung P, Hong-Gonzalez J, Freedland SJ, Said J et al. 2006 Effect of altering dietary omega-6/omega-3 fatty acid ratios on prostate cancer membrane composition, cyclooxygenase-2, and prostaglandin $\mathrm{E}_{2}$. Clinical Cancer Research 12 4662-4670. (doi:10.1158/1078-0432.CCR-06-0459)

Kote-Jarai Z, Olama AA, Giles GG, Severi G, Schleutker J, Weischer M, Campa D, Riboli E, Key T, Gronberg H et al. 2011 Seven prostate cancer susceptibility loci identified by a multi-stage genome-wide association study. Nature Genetics 43 785-791. (doi:10.1038/ ng.882)

Landau D, Tsakok T, Aylwin S \& Hughes S 2012 Should testosterone replacement be offered to hypogonadal men treated previously for prostatic carcinoma? Clinical Endocrinology 76 179-181. (doi:10.1111/j.1365-2265. 2011.04233.x)

Li H, Stampfer MJ, Mucci L, Rifai N, Qiu W, Kurth T \& Ma J 2010 A 25-year prospective study of plasma adiponectin and leptin concentrations and prostate cancer risk and survival. Clinical Chemistry 56 34-43. (doi:10.1373/ clinchem.2009.133272)

Lichtenstein P, Holm NV, Verkasalo PK, Iliadou A, Kaprio J, Koskenvuo M, Pukkala E, Skytthe A \& Hemminki K 2000 Environmental and heritable factors in the causation of cancer - analyses of cohorts of twins from Sweden, Denmark, and Finland. New England Journal of Medicine 343 78-85. (doi:10.1056/NEJM200007133430201)

Liverman CT \& Blazer DG, eds 2004 In Testosterone and aging: clinical research directives. Washington, DC, USA: The National Academy Press.

Locke JA, Guns ES, Lehman ML, Ettinger S, Zoubeidi A, Lubik A, Margiotti K, Fazli L, Adomat H, Wasan KM et al. 2010 Arachidonic acid activation of intratumoral steroid synthesis during prostate cancer progression to castration resistance. Prostate 70 239-251. (doi:10.1002/ pros.21057)

Lu S \& Archer MC 2010 Sp1 coordinately regulates de novo lipogenesis and proliferation in cancer cells. International Journal of Cancer 126 416-425. (doi:10.1002/ijc.24761)

Lu Y, Zhang Z, Yu H, Zheng SL, Isaacs WB, Xu J \& Sun J 2011 Functional annotation of risk loci identified through genome-wide association studies for prostate cancer. Prostate 71 955-963. (doi:10.1002/pros.21311)

Lund Haheim L, Wisloff TF, Holme I \& Nafstad P 2006 Metabolic syndrome predicts prostate cancer in a cohort of middle-aged Norwegian men followed for 27 years. American Journal of Epidemiology 164 769-774. (doi:10.1093/aje/kwj284)

Ly LP, Sartorius G, Hull L, Leung A, Swerdloff RS, Wang C \& Handelsman DJ 2010 Accuracy of calculated free testosterone formulae in men. Clinical Endocrinology $\mathbf{7 3}$ 382-388. (doi:10.1111/j.1365-2265.2010.03804.x)

Ma J, Li H, Giovannucci E, Mucci L, Qiu W, Nguyen PL, Gaziano JM, Pollak M \& Stampfer MJ 2008 Prediagnostic body-mass index, plasma C-peptide concentration, and prostate cancer-specific mortality in men with prostate cancer: a long-term survival analysis. Lancet Oncology 9 1039-1047. (doi:10.1016/S1470-2045(08)70235-3)

MacInnis RJ \& English DR 2006 Body size and composition and prostate cancer risk: systematic review and metaregression analysis. Cancer Causes \& Control 17 989-1003. (doi:10.1007/s10552-006-0049-z)

Mah PM \& Wittert GA 2010 Obesity and testicular function. Molecular and Cellular Endocrinology 316 180-186. (doi:10.1016/j.mce.2009.06.007)

Marks LS, Mazer NA, Mostaghel E, Hess DL, Dorey FJ, Epstein JI, Veltri RW, Makarov DV, Partin AW, Bostwick DG et al. 2006 Effect of testosterone replacement therapy on prostate tissue in men with lateonset hypogonadism: a randomized controlled trial. Journal of the American Medical Association 296 2351-2361. (doi:10.1001/jama.296.19.2351)

Marks LS, Mostaghel EA \& Nelson PS 2008 Prostate tissue androgens: history and current clinical relevance. Urology 72 247-254. (doi:10.1016/j.urology.2008.03.033) 
Martin RM, Vatten L, Gunnell D, Romundstad P \& Nilsen TI 2009 Components of the metabolic syndrome and risk of prostate cancer: the HUNT 2 cohort, Norway. Cancer Causes \& Control 20 1181-1192. (doi:10.1007/s10552009-9319-x)

McEntee MF, Ziegler C, Reel D, Tomer K, Shoieb A, Ray M, Li X, Neilsen N, Lih FB, O'Rourke D et al. 2008 Dietary $n-3$ polyunsaturated fatty acids enhance hormone ablation therapy in androgen-dependent prostate cancer. American Journal of Pathology 173 229-241. (doi:10.2353/ajpath. 2008.070989)

Meyer TE, Boerwinkle E, Morrison AC, Volcik KA, Sanderson M, Coker AL, Pankow JS \& Folsom AR 2010 Diabetes genes and prostate cancer in the Atherosclerosis Risk in Communities study. Cancer Epidemiology, Biomarkers \& Prevention 19 558-565. (doi:10.1158/ 1055-9965.EPI-09-0902)

Misra UK, Kaczowka S \& Pizzo SV 2010 Inhibition of NF-kappaB1 and NF-kappaB2 activation in prostate cancer cells treated with antibody against the carboxyl terminal domain of GRP78: effect of p53 upregulation. Biochemical and Biophysical Research Communications 392 538-542. (doi:10.1016/j.bbrc.2010.01.058)

Morgentaler A 2011 Testosterone and prostate cancer: what are the risks for middle-aged men? Urologic Clinics of North America 38 119-124. (doi:10.1016/j.ucl.2011. 02.002)

Morgentaler A \& Traish AM 2009 Shifting the paradigm of testosterone and prostate cancer: the saturation model and the limits of androgen-dependent growth. European Urology 55 310-320. (doi:10.1016/j.eururo. 2008.09.024)

Neuhouser ML, Till C, Kristal A, Goodman P, Hoque A, Platz EA, Hsing AW, Albanes D, Parnes HL \& Pollak M 2010 Finasteride modifies the relation between serum C-peptide and prostate cancer risk: results from the Prostate Cancer Prevention Trial. Cancer Prevention Research 3 279-289. (doi:10.1158/1940-6207.CAPR09-0188)

Nguyen PL, Je Y, Schutz FA, Hoffman KE, Hu JC, Parekh A, Beckman JA \& Choueiri TK 2011 Association of androgen deprivation therapy with cardiovascular death in patients with prostate cancer: a meta-analysis of randomized trials. Journal of the American Medical Association 306 2359-2366. (doi:10.1001/ jama.2011.1745)

Onuma M, Bub JD, Rummel TL \& Iwamoto Y 2003 Prostate cancer cell-adipocyte interaction: leptin mediates androgen-independent prostate cancer cell proliferation through c-Jun NH2-terminal kinase. Journal of Biological Chemistry 278 42660-42667. (doi:10.1074/jbc. M304984200)

Page ST, Lin DW, Mostaghel EA, Marck BT, Wright JL, Wu J, Amory JK, Nelson PS \& Matsumoto AM 2011 Dihydrotestosterone administration does not increase intraprostatic androgen concentrations or alter prostate androgen action in healthy men: a randomizedcontrolled trial. Journal of Clinical Endocrinology and Metabolism 96 430-437. (doi:10.1210/jc.2010-1865)

Risbridger GP, Davis ID, Birrell SN \& Tilley WD 2010 Breast and prostate cancer: more similar than different. Nature Reviews. Cancer 10 205-212. (doi:10.1038/ $\operatorname{nrc} 2795)$

Roddam AW, Allen NE, Appleby P \& Key TJ $2008 a$ Endogenous sex hormones and prostate cancer: a collaborative analysis of 18 prospective studies. Journal of the National Cancer Institute 100 170-183. (doi:10.1093/jnci/djm323)

Roddam AW, Allen NE, Appleby P, Key TJ, Ferrucci L, Carter HB, Metter EJ, Chen C, Weiss NS, Fitzpatrick A et al. $2008 b$ Insulin-like growth factors, their binding proteins, and prostate cancer risk: analysis of individual patient data from 12 prospective studies. Annals of Internal Medicine 149 461-471. W483-468.

Rodriguez C, Patel AV, Mondul AM, Jacobs EJ, Thun MJ \& Calle EE 2005 Diabetes and risk of prostate cancer in a prospective cohort of US men. American Journal of Epidemiology 161 147-152. (doi:10.1093/aje/kwh334)

Rodriguez C, Freedland SJ, Deka A, Jacobs EJ, McCullough ML, Patel AV, Thun MJ \& Calle EE 2007 Body mass index, weight change, and risk of prostate cancer in the Cancer Prevention Study II Nutrition Cohort. Cancer Epidemiology, Biomarkers \& Prevention 16 63-69. (doi:10.1158/1055-9965.EPI-06-0754)

Rowlands MA, Gunnell D, Harris R, Vatten LJ, Holly JM \& Martin RM 2009 Circulating insulin-like growth factor peptides and prostate cancer risk: a systematic review and meta-analysis. International Journal of Cancer 124 2416-2429. (doi:10.1002/ijc.24202)

Salonia A, Gallina A, Briganti A, Abdollah F, Suardi N, Capitanio U, Colombo R, Freschi M, Rigatti P \& Montorsi F 2011 Preoperative hypogonadism is not an independent predictor of high-risk disease in patients undergoing radical prostatectomy. Cancer 117 3953-3962. (doi:10.1002/cncr.25985)

Satariano WA, Ragland KE \& Van Den Eeden SK 1998 Cause of death in men diagnosed with prostate carcinoma. Cancer 83 1180-1188. (doi:10.1002/(SICI)1097-0142(19980915) 83:6<1180::AID-CNCR18>3.0.CO;2-1)

Shahinian VB 2011 Androgen deprivation for prostate cancer: the case for "first, do no harm". Cancer [in press]. (doi:10.1002/cncr.26624)

Shaw JE, Sicree RA \& Zimmet PZ 2010 Global estimates of the prevalence of diabetes for 2010 and 2030. Diabetes Research and Clinical Practice 87 4-14. (doi:10.1016/ j.diabres.2009.10.007)

Siegel R, Ward E, Brawley O \& Jemal A 2011 Cancer statistics, 2011: the impact of eliminating socioeconomic and racial disparities on premature cancer deaths. CA: A Cancer Journal for Clinicians 61 212-236. (doi:10.3322/caac.20121)

Smith JC, Bennett S, Evans LM, Kynaston HG, Parmar M, Mason MD, Cockcroft JR, Scanlon MF \& Davies JS 2001 
The effects of induced hypogonadism on arterial stiffness, body composition, and metabolic parameters in males with prostate cancer. Journal of Clinical Endocrinology and Metabolism 86 4261-4267. (doi:10.1210/jc.86.9.4261)

Smith MR, Bae K, Efstathiou JA, Hanks GE, Pilepich MV, Sandler HM \& Shipley WU 2008 Diabetes and mortality in men with locally advanced prostate cancer: RTOG 92-02. Journal of Clinical Oncology 26 4333-4339. (doi:10.1200/JCO.2008.16.5845)

Stevens VL, Ahn J, Sun J, Jacobs EJ, Moore SC, Patel AV, Berndt SI, Albanes D \& Hayes RB 2010 HNF1B and JAZF1 genes, diabetes, and prostate cancer risk. Prostate 70 601-607. (doi:10.1002/pros.21094)

Stewart SB \& Freedland SJ 2011 Influence of obesity on the incidence and treatment of genitourinary malignancies. Urologic Oncology 29 476-486.

Su LJ, Arab L, Steck SE, Fontham ET, Schroeder JC, Bensen JT \& Mohler JL 2011 Obesity and prostate cancer aggressiveness among African and Caucasian Americans in a population-based study. Cancer Epidemiology, Biomarkers \& Prevention 20 844-853. (doi:10.1158/1055-9965.EPI-10-0684)

Svensson J, Kindblom J, Shao R, Moverare-Skrtic S, Lagerquist MK, Andersson N, Sjogren K, Venken K, Vanderschueren D, Jansson JO et al. 2008 Liver-derived IGF1 enhances the androgenic response in prostate. Journal of Endocrinology 199 489-497. (doi:10.1677/ JOE-08-0406)

Tamura K, Makino A, Hullin-Matsuda F, Kobayashi T, Furihata M, Chung S, Ashida S, Miki T, Fujioka T, Shuin T et al. 2009 Novel lipogenic enzyme ELOVL7 is involved in prostate cancer growth through saturated long-chain fatty acid metabolism. Cancer Research 69 8133-8140. (doi:10.1158/0008-5472.CAN-09-0775)

Tande AJ, Platz EA \& Folsom AR 2006 The metabolic syndrome is associated with reduced risk of prostate cancer. American Journal of Epidemiology 164 1094-1102. (doi:10.1093/aje/kwj320)

Van Hemelrijck M, Garmo H, Holmberg L, Walldius G, Jungner I, Hammar N \& Lambe M 2011 Prostate cancer risk in the Swedish AMORIS study: the interplay among triglycerides, total cholesterol, and glucose. Cancer 117 2086-2095. (doi:10.1002/cncr.25758)

Venkateswaran V, Haddad AQ, Fleshner NE, Fan R, Sugar LM, Nam R, Klotz LH \& Pollak M 2007 Association of diet-induced hyperinsulinemia with accelerated growth of prostate cancer (LNCaP) xenografts. Journal of the National Cancer Institute 99 1793-1800. (doi:10.1093/jnci/djm231)
Vikan T, Schirmer H, Njolstad I \& Svartberg J 2010 Low testosterone and sex hormone-binding globulin levels and high estradiol levels are independent predictors of type 2 diabetes in men. European Journal of Endocrinology 162 747-754. (doi:10.1530/EJE-09-0943)

Waters KM, Henderson BE, Stram DO, Wan P, Kolonel LN \& Haiman CA 2009 Association of diabetes with prostate cancer risk in the multiethnic cohort. American Journal of Epidemiology 169 937-945. (doi:10.1093/aje/kwp003)

Waters KM, Wilkens LR, Monroe KR, Stram DO, Kolonel LN, Henderson BE, Le Marchand L \& Haiman CA 2011 No association of type 2 diabetes risk variants and prostate cancer risk: the multiethnic cohort and PAGE. Cancer Epidemiology, Biomarkers \& Prevention 20 1979-1981. (doi:10.1158/1055-9965.EPI11-0019)

Willemarck N, Rysman E, Brusselmans K, Van Imschoot G, Vanderhoydonc F, Moerloose K, Lerut E, Verhoeven G, van Roy F, Vleminckx K et al. 2010 Aberrant activation of fatty acid synthesis suppresses primary cilium formation and distorts tissue development. Cancer Research 70 9453-9462. (doi:10.1158/0008-5472. CAN-10-2324)

Wittert GA, Chapman IM, Haren MT, Mackintosh S, Coates P \& Morley JE 2003 Oral testosterone supplementation increases muscle and decreases fat mass in healthy elderly males with low-normal gonadal status. Journals of Gerontology. Series A, Biological Sciences and Medical Sciences 58 618-625. (doi:10.1093/gerona/58.7.M618)

Yeh HC, Platz EA, Wang NY, Visvanathan K, Helzlsouer KJ \& Brancati FL 2012 A prospective study of the associations between treated diabetes and cancer outcomes. Diabetes Care 35 113-118. (doi:10.2337/ dc11-0255)

Zeggini E, Scott LJ, Saxena R, Voight BF, Marchini JL, Hu T, de Bakker PI, Abecasis GR, Almgren P, Andersen G et al. 2008 Meta-analysis of genome-wide association data and large-scale replication identifies additional susceptibility loci for type 2 diabetes. Nature Genetics $40638-645$. (doi:10.1038/ng.120)

Received in final form 11 April 2012

Accepted 17 April 2012 Made available online as an Accepted Preprint 18 April 2012 